\title{
Can Home Exercise Programs Be a Low-Cost Alternative to Multiple Sclerosis Treatment?
}

\section{Evde Egzersiz Programları Multipl Skleroz Tedavisinde Düşük Maliyetli Bir Alternatif Olabilir mi?}

\author{
Zeynep Aykın Yığman', @Özgür Zeliha Karaahmet², ®Ebru Umay², \Fatma Avşar Ertürk³, \\ (D)Bülent Güven ${ }^{3}$ \\ Polatlı Duatepe State Hospital, Clinic of Physical Medicine and Rehabilitation, Ankara, Turkey \\ University of Health Sciences, Ankara Dışkapı Yıldırım Beyazıt Health Research Center, Department of Physical Medicine and Rehabilitation, \\ Ankara, Turkey \\ University of Health Sciences, Ankara Dışkapı Yıldırım Beyazıt Health Research Center, Department of Neurology, Ankara, Turkey
}

\begin{abstract}
Aim: In this study, we aimed to compare the effect of aerobic exercise programs on patients with Multiple Sclerosis (MS) and healthy controls, and to show that home exercise programs can be as effective as supervised exercise programs.
\end{abstract}

Material and Method: Eighty participants were included in this study and were divided into groups as the home-exercise group (outpatient), supervised exercise group (inpatient), and healthy controls. A 6-weeks aerobic exercise program was given to all participants. Before and after the exercise program, 6-Minute Walking Test (6MWT), Fatigue Severity Scale (FSS), Modified Ashworth Scale (MAS), Berg Balance Scale (BBS), Extended Disability Scale (EDSS), Cardiopulmonary Exercise Test (CPET), and MS Quality of Life (MSQoL-54) were applied to participants.

Results: When 6MWT and CPET data were evaluated, it was observed that the patient and control groups benefited from the exercise program. There was a significant improvement after treatment in the 6MWT, BBS, FSS, MSQoL-54, and CPET data of both the outpatient and inpatient groups, and there was no difference between the groups when the rates of change were compared.

Conclusion: We have observed that the home-based exercise program is as effective as the supervised exercise program. We think that the home program should be recommended first when planning the exercise program in PwMS in terms of cost, effectiveness, and accessibility.

Keywords: aerobic exercise, fatigue, multiple sclerosis, quality of life, rehabilitation

\section{Öz}

Amaç: Bu çalışmada, aerobik egzersiz programlarının Multipl Skleroz (MS) hastaları ve sağlıklı kontroller üzerindeki etkisini karşılaştırmayı ve ev egzersiz programlarının denetimli egzersiz programları kadar etkili olabileceğini göstermeyi amaçladık.

Gereç ve Yöntem: Seksen katılımcı bu çalışmaya dahil edildi ve evde egzersiz grubu (ayaktan tedavi), denetimli egzersiz grubu (yatarak tedavi) ve sağlıklı kontroller olarak gruplara ayrıldı. Tüm katılımcılara 6 haftalık aerobik egzersiz programı verildi. Egzersiz programı öncesi ve sonrası, 6 Dakika Yürüme Testi (6DYT), Yorgunluk Şiddet Ölçeği (YŞÖ), Modifiye Ashworth Ölçeği (MAÖ), Berg Denge Ölçeği (BDÖ), Genişletilmiş Yetersizlik Düzeyi Ölçeği (EDSS), Kardiyopulmoner Egzersiz Testi (KPET), ve MS Yaşam Kalitesi Ölçeği (MSYKÖ-54) katılımcılara uygulandı.

Bulgular: 6DYT ve KPET verileri değerlendirildiğinde hasta ve kontrol gruplarının egzersiz programından yararlandığı görüldü. Hem ayaktan hem de yatan hasta gruplarının 6DYT, BDÖ, YŞÖ, MSYKÖ-54 ve KPET verilerinde tedavi sonrası anlamlı düzelme oldu ve değişim oranları karşılaştırıldığında gruplar arasında fark yoktu.

Sonuç: Ev temelli egzersiz programının denetimli egzersiz programı kadar etkili olduğunu gözlemledik. Maliyet, etkinlik ve erişilebilirlik açısından MS hastalarda egzersiz programı planlanırken öncelikle ev programının önerilmesi gerektiğini düşünüyoruz.

Anahtar Kelimeler: aerobik egzersiz, multipl skleroz, rehabilitasyon, yorgunluk, yaşam kalitesi 


\section{INTRODUCTION}

Multiple sclerosis (MS); is a chronic, demyelinating and neurodegenerative disease that often affects young adults. ${ }^{[1]}$ According to the review of 30 studies examining the incidence and prevalence, the male/female ratio is 1.00/1.77. ${ }^{[2]}$ Multiple sclerosis can develop at any stage of life. However, most studies reported a mean age of onset between 29 and 32. ${ }^{[3]}$

The symptoms of patients with MS (PwMS) vary according to the localization and size of the demyelinated areas; that may come up with complaints such as functional disorders, spasticity, muscle weakness, fatigue, pain, sensory symptoms, bladder problems, intestinal problems, blurred vision, optic neuritis, sexual dysfunctions, tremor, emotional lability, walking and balance disorder. ${ }^{[4]}$

Rehabilitation in MS is a dynamic process that changes according to the changing symptoms of the disease and must be constantly updated. ${ }^{[5]} \mathrm{MS}$ is a lifelong disease; so rehabilitation of the disease should not only be a periodical treatment program, but should be made a lifestyle with the active participation of the patient as much as possible. ${ }^{[5]}$

Aerobic exercises are low-intensity, rhythmic, dynamic, and long-term activities performed using large muscle groups. They also increase endurance, which is the ability to do work for a long time. Examples of these exercises are activities such as walking, cycling, running, dancing, swimming. ${ }^{[6-8]}$

Experimental evidence reports that aerobic exercise and rehabilitation increase the satisfaction of the PwMS on their physical, mental and social functionality and they can be included as a routine treatment in MS. ${ }^{[9,10]}$ Since aerobic exercise performed on a treadmill also provides a high volume of taskspecific practice, aerobic treadmill training has the potential to improve walking ability, fitness, and quality of life (QoL). ${ }^{[11]}$

The positive effects of aerobic exercise on walking performance, cardiorespiratory fitness, balance, quality of life, cognitive status, fatigue, and depressive symptoms in PwMS have been demonstrated in various studies. ${ }^{[12-15]}$ In addition, studies have shown that maximum oxygen consumption volume ( $\left.\mathrm{VO}_{2} \mathrm{max}\right)$ in PwMS is lower than healthy controls and can be increased with aerobic exercise training. ${ }^{[16,17]}$

Numerous researchers have examined the impact of intervention involving aerobic exercise training on quality of life in PwMS. However, there are conflicting results among past research on the effect of exercise on quality of life in MS. Such researches emphasizes the importance of conducting a quantitative synthesis documenting the magnitude of the overall impact of exercise education on quality of life in PwMS. $[9,18]$

Our aims in this study; 1) Evaluating the effects of aerobic exercise programs on fatigue, disability, spasticity, balance, aerobic capacity, and quality of life in PwMS, 2) Comparing home aerobic exercise programs with supervised aerobic exercise programs in PwMS; 3) To compare the effects of aerobic exercise programs on PwMS and healthy controls.

\section{MATERIAL AND METHOD}

\section{Ethical Statement}

This study was approved by the local Institutional Ethics Committee and was conducted in accordance with the Declaration of Helsinki guidelines. Signed informed consent was obtained from each participant before starting data collection.

\section{Study Design and Participants}

This prospective, randomized controlled clinical study evaluated PwMS, who presented to the physical medicine and rehabilitation (PMR) clinic between January and June 2019.

Patients aged 18-70 years, with EDSS score of $<5,5$, clinically stable, and not exercising regularly were included study. Patients who were regularly exercising for the past six months, with neurological disease other than MS, with severe cardiorespiratory system disease, with severe orthopedic impairment or gait problems, cognitive or mental disability were not included in the study.

Participants were tried to be randomized by using the opaque envelope method. Randomization was conducted by a clinical secretary who was not involved in the study. Patients were divided into groups as "outpatient group" (home exercise program) and "inpatient group" (supervised exercise program). The control group was created sex- and age-matched healthy volunteers including patient relatives or caregivers or health workers.

The sample size was made using the $G *$ power (V3.1.7) program, and to create a minimum change of 10 units in visual analog scale; at least 20 patients were found for each group with $a=0.05,80 \%$ power and $d=0.631$ effect size. The sample size was also compatible with similar previous studies.

The study included 27 outpatients, 27 inpatients, and 27 healthy controls. Since one from the outpatient group did not want to continue the exercise program, so he was excluded. The study was completed with 53 patients and 27 healthy controls (Figure 1).

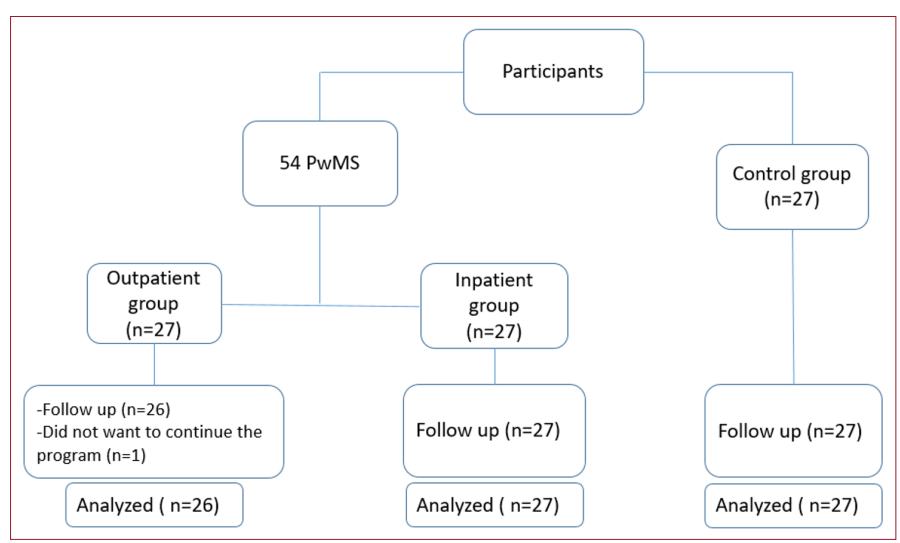

Figure 1. Flow chart of the study

PwMS: Patients with Multiple Sclerosis 


\section{Disease and Demographic Characteristics}

Sociodemographic and clinical data of the participants were recorded in the forms prepared by the researchers. Demographic characteristics including sex, age, body mass index (BMI) and years of education of the participants, as well as disease characteristics of the patients were recorded.

\section{Outcome Parameters}

Modified Ashworth Scale (MAS), 6-minute walking test (6MWT), Fatigue Severity Scale (FSS), Extended Disability Status Scale (EDSS), Berg Balance Scale (BBS), cardiopulmonary exercise test (CPET), and Multiple Sclerosis Quality of Life-54 (MSQoL-54) questionnaire were performed before and after the 6-week exercise program.

All the participants in this study were subjected to a $6 \mathrm{MWT}^{[19]}$ and CPET to determine their aerobic capacity before the exercise program. Also, these tests were performed after treatment.

Cardiopulmonary exercises test was applied to each participant to determine their exercise capacity. Before the test, each participant was introduced to the device and an information form was given. The Care Fusion Type Master Screen-CPX device performed CPET with Bruce protocol on the treadmill. During the test, the patients continued to breathe with a mask fitted with a gas meter at the end, allowing the measurement of oxygen and carbon dioxide. During the test, electrocardiography was followed. The exercise test was terminated if the patient reported a degree of fatigue of 15-17 on the Borg Scale, ${ }^{[20]}$ stated that participant could not continue exercising for any reason, or when the indications for completing the exercise test appeared. Maximum time, $\mathrm{VO}_{2}$ max, resting heart rate, maximum heart rate (HRmax), metabolic equivalent (MET), peak work rate (WRpeak) values achieved during the test were recorded.

Modified Ashworth Scale (MAS); was used for the assessment of spasticity and it was scored between $0-4 .{ }^{[21]}$

Kurtzke's Extended Disability Status Scale; describes the severity of disability in 8 functional systems in PwMS, and high scores represent higher levels of disability. ${ }^{[2]}$

Fatigue Severity Scale; consists of 9 questions (1-7 points) that measure the severity of fatigue and its effect on one's activities. High scores indicate severe fatigue. ${ }^{[23]}$

Berg Balance Scale; includes 14 general balance activities and scores between $0-4$ by observing the patient's performance for each activity. Total score was calculated between 0 and 56 points. ${ }^{[24]}$

Multiple Sclerosis Quality of Life-54 questionnaire; consists of 2 main groups (Physical Health Composite [PHC], Mental Health Composite $[\mathrm{MHC}]), 13$ subgroups and 2 independent items. The subscales evaluate health between 0 and 100 points (0:poor health conditions / 100: good health conditions). ${ }^{[25]}$ In this study, main groups were scored separately.

Aerobic exercise program was prescribed to all the subjects according to the $\mathrm{VO}_{2}$ max obtained in the exercise tolerance test.
Home exercise program was given to the outpatient group and the control group for 6 weeks, 5 days a week. In each exercise session, brisk walking with a maximum intensity of $60-80 \%$ of the maximum heart rate for 30 minutes between 5 minutes of warm-up and cooling periods (breathing, flexibility, posture, stretching, and balance exercises) was recommended. The patients were checked for their compliance with the exercises by calling the phone numbers given once a week, the necessary information was given, and they were motivated for the continuation of the exercises.

For the inpatient group, for a period of 6 weeks, 5 days a week, walking on a treadmill or cycling at the intensity of $60-80 \%$ of the maximum heart rate for 30 minutes between 5 minutes of warm-up and cooling periods in each exercise session was run. Patients were given breathing, flexibility, posture, stretching, and balance exercises under supervision, twice a day.

\section{Statistical Analysis}

The analysis of the data was done in SPSS for Windows 15.0 package program. Descriptive statistics were shown as mean \pm standard deviation for continuous variables and number of observations and (\%) for nominal variables. During the analysis, it was evaluated whether there was a significant difference between the before and after values for each group. The percentage changes were taken as the basis when comparing the rates of change in the groups. Paired Sample t-test was used to compare the exercise program start and end values of the groups. Two samples t-test and Kruskal Wallis test were used to compare the rates of change between groups. $p<0.05$ was considered significant for the results.

\section{RESULTS}

Twenty-seven healthy participants and 53 PwMS participated in the study. Comparison of the demographic data of the participants was given in Table 1. There was no significant difference between the groups except for the years of education.

According to the post-hoc Tamhane T2 results, a significant difference was found between the control group and both the outpatient group $(p=0.002)$ and the inpatient group $(p=0.000)$, due to the high educational years of the control group.

Table 1. Comparison of the demographic data of the patient and control groups

\begin{tabular}{|c|c|c|c|c|}
\hline & $\begin{array}{l}\text { Outpatient } \\
(n=26)\end{array}$ & $\begin{array}{c}\text { Inpatient } \\
(\mathrm{n}=\mathbf{2 7})\end{array}$ & $\begin{array}{l}\text { Control } \\
(n=27)\end{array}$ & $\mathbf{p}$ \\
\hline Age mean (SD) & $41.81(9.20)$ & $44.96(9.70)$ & 39.93 (10.76) & .222 \\
\hline \multirow{2}{*}{ Sex n (\%) } & $4(15.4 \%)$ & $8(29.6 \%)$ & $5(18.5 \%)$ & \multirow{2}{*}{.414} \\
\hline & $22(84.6 \%)$ & $19(70.4 \%)$ & 22 (81.5\%) & \\
\hline $\begin{array}{l}\text { Education years } \\
\text { mean (SD) }\end{array}$ & $8.96(4.20)$ & $8.19(4.30)$ & $13.63(5.09)$ & $.000^{*}$ \\
\hline BMI mean (SD) & $26.82(5.74)$ & $25.19(5.60)$ & 25.79 (3.42) & .343 \\
\hline $\begin{array}{l}\text { Disease durations } \\
\text { mean (SD) }\end{array}$ & $8.08(5.26)$ & $9.81(8.11)$ & & $.872 a$ \\
\hline
\end{tabular}


Comparison of 6MWT and CPET values before and after treatment, within and between healthy control, inpatient, and outpatient groups were presented in Table 2. The increase in 6MWT was significant for all groups [inpatient $(p=0.010)$, outpatient $(p=0.000)$, control $(p=0.000)]$. There was a significant increase in $\mathrm{VO}_{2} \max (p=0.001)$, MET $(p=0.009)$, time $(p=0.000)$ and WRpeak $(p=0.005)$ values in the inpatient group, and a significant increase in $\mathrm{VO}_{2} \max (\mathrm{p}=0.017), \mathrm{HRmax}$ $(p=0.003)$ and time $(p=0.006)$ values in the outpatient group. There were also significant increases in $\mathrm{VO}_{2} \max (p=0.000)$, HRmax $(p=0.025)$, MET $(p=0.000)$, duration $(p=0.001)$ and WRpeak $(p=0.000)$ in the healthy control group.

Changes in 6MWT and CPET data between groups, before and after treatment were evaluated with the Kruskal Wallis test. As a result of the analysis, a difference was found between the groups only in the change of CPET time, and according to the post-hoc Tamhane's T2 results, there was a difference between the control group and the inpatient group due to more change in inpatients $(p=0.029)$.

Comparison of MAS, EDSS, FSS, BBS and MSQoL-54 (PHC and $\mathrm{MHC}$ ) results before and after treatment, within and between inpatient and outpatient groups were shown in Table 3. Significant improvement was observed in the MAS $(p=0.043)$, FSS $(p=0.000), B B S(p=0.000)$, and MSQoL-54 PHC $(p=0.000)$ scores in the inpatient group after treatment. Significant improvement was found in the EDSS $(p=0.006)$, FSS $(p=0.002)$, BBS $(p=0.000)$, MSQoL-54 PHC $(p=0.000)$, and MSQoL-54 MHC $(p=0.022)$ scores in the outpatient group. When the posttreatment changes were compared between the outpatient and inpatient groups, no significant difference was found except for EDSS ( $p=0.036)$.

\section{DISCUSSION}

It is known that in the past, clinicians avoided exercise programs in PwMS, believing that it would increase spasticity. However, studies have shown that exercise program has positive effects such as increasing physical and motor functions, reducing spasticity, improving proprioception and balance. ${ }^{[9,26]}$ In addition, aerobic exercise can improve physical, psychological, and mental health through various mechanisms that reduce pain and fatigue, the two main symptoms of MS. ${ }^{[9,13]}$ In our study, it has been determined that fatigue, spasticity, and balance problems of the patients decreased with aerobic exercise. When the effect of the home program and the supervised exercise program was compared, no significant difference was found between the groups in terms of fatigue, spasticity, and balance changes. However, it was determined that the home program was significantly more effective in terms of EDSS change. The cause why there was no difference between the pretreatment EDSS scores and more improvement in the homeexercise group may be that the individual continues his daily activities at the same time as the exercise program or is in his social life.

\begin{tabular}{|c|c|c|c|c|c|c|c|c|c|c|}
\hline \multirow{2}{*}{ Variables } & \multicolumn{3}{|c|}{ Control group ( $n=27$ ) Mean (SD) } & \multicolumn{3}{|c|}{ Inpatient Group ( $n=27$ ) Mean (SD) } & \multicolumn{3}{|c|}{ Outpatient Group (n=26) Mean (SD) } & \multirow{2}{*}{$\mathbf{p}^{* *}$} \\
\hline & BT & AT & $\mathbf{p}$ & BT & AT & $\mathbf{p}$ & BT & AT & $\mathbf{p}$ & \\
\hline 6MWT (m) & $\begin{array}{l}526.30 \\
(75.87)\end{array}$ & $\begin{array}{l}558.89 \\
(85.74)\end{array}$ & $.000^{*}$ & $\begin{array}{c}373.15 \\
(186.54)\end{array}$ & $\begin{array}{c}397.96 \\
(178.30)\end{array}$ & $.010^{*}$ & $\begin{array}{c}408.46 \\
(151.02)\end{array}$ & $\begin{array}{c}443.85 \\
(150.38)\end{array}$ & $.000^{*}$ & .482 \\
\hline $\begin{array}{l}\text { CPET VO } 2 \text { max (ml/ } \\
\mathrm{kg} / \mathrm{mins})\end{array}$ & $\begin{array}{l}1601.00 \\
(358.01)\end{array}$ & $\begin{array}{l}1766.22 \\
(332.47)\end{array}$ & $.000^{*}$ & $\begin{array}{c}820.93 \\
(271.34)\end{array}$ & $\begin{array}{l}1004.52 \\
(333.28)\end{array}$ & $.001^{*}$ & $\begin{array}{c}908.23 \\
(491.22)\end{array}$ & $\begin{array}{l}1001.54 \\
(484.96)\end{array}$ & $.017^{*}$ & .272 \\
\hline $\begin{array}{l}\text { CPET rp (beats/ } \\
\text { mins) }\end{array}$ & $\begin{array}{l}85.85 \\
(13.11)\end{array}$ & $\begin{array}{c}86.37 \\
(10.32)\end{array}$ & .796 & $\begin{array}{c}90.04 \\
(17.16)\end{array}$ & $\begin{array}{c}86.41 \\
(11.72)\end{array}$ & .266 & $\begin{array}{c}88.31 \\
(14.57)\end{array}$ & $\begin{array}{c}90.08 \\
(10.64)\end{array}$ & .515 & .429 \\
\hline $\begin{array}{l}\text { CPET HRmax } \\
\text { (beats/mins) }\end{array}$ & $\begin{array}{l}153.74 \\
(23.31)\end{array}$ & $\begin{array}{l}159.81 \\
(24.15)\end{array}$ & $.025^{*}$ & $\begin{array}{l}115.78 \\
(21.55)\end{array}$ & $\begin{array}{l}121.00 \\
(24.09)\end{array}$ & .187 & $\begin{array}{l}116.12 \\
(19.67)\end{array}$ & $\begin{array}{l}125.27 \\
(18.17)\end{array}$ & $.003^{*}$ & .476 \\
\hline CPET MET & $\begin{array}{c}6.44 \\
(1.74)\end{array}$ & $\begin{array}{c}6.85 \\
(1.80)\end{array}$ & $.000^{*}$ & $\begin{array}{c}3.64 \\
(1.47)\end{array}$ & $\begin{array}{c}4.20 \\
(1.84)\end{array}$ & $.009^{*}$ & $\begin{array}{c}3.73 \\
(1.77)\end{array}$ & $\begin{array}{c}4.04 \\
(1.68)\end{array}$ & .094 & .321 \\
\hline CPET time (mins) & $\begin{array}{c}8.79 \\
(2.59)\end{array}$ & $\begin{array}{c}9.87 \\
(2.53)\end{array}$ & $.001^{*}$ & $\begin{array}{l}5.27 \\
(2.52)\end{array}$ & $\begin{array}{c}7.22 \\
(3.38)\end{array}$ & $.000^{*}$ & $\begin{array}{c}5.52 \\
(2.30)\end{array}$ & $\begin{array}{c}6.85 \\
(2.69)\end{array}$ & $.006^{*}$ & $.014^{*}$ \\
\hline CPET WRpeak (W) & $\begin{array}{l}169.59 \\
(63.34)\end{array}$ & $\begin{array}{l}197.93 \\
(70.34)\end{array}$ & $.000^{*}$ & $\begin{array}{c}38.52 \\
(42.97)\end{array}$ & $\begin{array}{c}56.30 \\
(50.46)\end{array}$ & $.005^{*}$ & $\begin{array}{c}60.27 \\
(60.65)\end{array}$ & $\begin{array}{c}70.65 \\
(64.10)\end{array}$ & .156 & .293 \\
\hline
\end{tabular}

\begin{tabular}{|c|c|c|c|c|c|c|c|}
\hline \multirow{2}{*}{ Variables } & \multicolumn{3}{|c|}{ Inpatient Group (n=27) Mean (SD) } & \multicolumn{3}{|c|}{ Outpatient Group (n=26) Mean (SD) } & \multirow{2}{*}{$\mathbf{P} * *$} \\
\hline & BT & AT & $\mathbf{p}$ & BT & AT & $p$ & \\
\hline MAS & $1.26(.45)$ & $1.11(.32)$ & $.043^{*}$ & $1.15(.46)$ & $1.08(.27)$ & .161 & .318 \\
\hline EDSS & $3.67(1.54)$ & $3.65(1.53)$ & .574 & $4.17(.71)$ & $4.04(.79)$ & $.006^{*}$ & $.036^{*}$ \\
\hline FSS & $22.81(12.27)$ & $18.30(10.92)$ & $.000^{*}$ & $21.19(9.74)$ & $15.96(10.49)$ & $.002^{*}$ & .696 \\
\hline BBS & $45.07(9.70)$ & $47.37(8.17)$ & $.000^{*}$ & $49.23(5.60)$ & $51.35(4.51)$ & $.000^{*}$ & .372 \\
\hline MSQoL-54 PHC & $55.53(18.24)$ & $62.25(18.63)$ & $.000^{*}$ & $57.77(19.83)$ & $66.94(17.89)$ & $.000^{*}$ & .360 \\
\hline MSQoL-54 MHC & $56.19(18.15)$ & $59.57(18.58)$ & .120 & 55.01 (19.29) & $62.40(17.87)$ & $.022 *$ & .128 \\
\hline
\end{tabular}


As stated in previous studies, PwMS has a low QoL due to disease-related symptoms..$^{[9]}$ The effect of exercise on QoL is affected by many variables (age, gender, disease duration, disability level). It is thought that more experimental studies are needed in this area. In this study, we evaluated the quality of life in PWMS with a disease-specific scale. ${ }^{[27]}$ In this study, when the MSQoL-54 data of PwMS treated as outpatient and inpatient were evaluated; significant improvements were found in $\mathrm{PHC}$ and $\mathrm{MHC}$ values in the outpatient group. There was a significant difference in PHC values in the inpatient group. When the change in the outpatient and inpatient groups was compared, there was no significant difference in MSQoL-54 data. After a regular aerobic exercise program, increased physical activity, decreased fatige, increased stability, increased functionality, and decreased disability can improve overall health perception and improved quality of life.

Walking disorder is a common and life-affecting parameter in PwMS. In studies have found a relationship between walking speed and muscle strength in PwMS, and it has been reported that PwMS has a lower walking speed than its healthy peers. ${ }^{[2-30]}$ In line with these results, it was found in the current study that PwMS walked slower than healthy controls during the 6MWT. Studies have shown that aerobic exercise training improves walking resistance in PwMS. ${ }^{[9,31]}$ Similarly, in this study, a significant improvement was observed in the 6-minute walking distance in patients and control groups after the aerobic exercise program. When the rates of change between the patient and control groups were compared, no significant difference was found between the three groups. The obtained data support the positive effects of the exercise program on walking speed, endurance, and ability in PwMS.

Previous studies have shown that $\mathrm{VO}_{2}$ max, HRmax, WRpeak data in PwMS are significantly lower than in healthy controls, and cardiopulmonary capacity can be improved with adequate time and intensity aerobic exercise training. ${ }^{[32-35]}$ Similarly, in this study, $\mathrm{VO}_{2} \max$, HRmax, WRpeak were found to be lower in PwMS. Low $\mathrm{VO}_{2}$ max, HRmax, WRpeak levels in PwMS can generally be associated with low physical activity in these patients. ${ }^{[36]}$ The reason for low physical activity may be due to the patient's current symptoms or may be due to their avoidance of physical activity, thinking that increased physical activity will cause the fatigue and weakness $(37,38)$. In addition, symptoms such as balance-coordination disorder, spasticity, muscle weakness, and cooperation disorder in PwMS may adversely affect the results obtained during the exercise test. ${ }^{[34,35]}$ In addition, musculoskeletal disorders associated with obesity and aging may adversely affect the evaluation of CPET. The disadvantage of our study is that the age range of the participants was wide and additional issues related to aging were not evaluated. Despite randomization was performed in our study, no difference was found between the three groups in terms of age, gender, and BMI, and we accepted that additional issues related to aging and weight were similar between the groups.
When the change in CPET values of the patients and control groups was compared, the improvement in duration was greater in the inpatient group. There was no significant difference between all three groups in other CPET data. According to the results, the exercise program increased aerobic capacity in both the patients and control groups. When the changes in CPET values after treatment in outpatient and inpatient groups were compared, there was no significant difference to be found. According to these results, we can say that outpatient and inpatient groups benefit from aerobic exercise programs at similar rates. Considering that the home program and the supervised program have similar benefits, we may prefer the home exercise program first because of cost and easy accessibility. In addition, similar changes were obtained in the patient groups and the control group, suggesting that although PwMS have spasticity, balance disorder, or muscle weakness, they can benefit from a regular exercise program as much as healthy controls.

According to the data we obtained as a result of our study; aerobic exercise improves fatigue, quality of life, balance, spasticity, walking performance, and cardiopulmonary capacity in PwMS. Although the participants benefited from both programs (supervised exercise program and home program) at similar rates, the fact that the decrease in disability level was more common in the home program made the home program more advantageous in terms of both low cost and easy accessibility. In addition, we found that although the aerobic capacity was low in PwMS, a similar change in aerobic capacity could be achieved with the healthy controls by applying for the same exercise program.

The limitation of the current study is that patients with an EDSS score $<5.5$ were included in this study, so the effect of the exercise program on severely disabled patients could not be evaluated. In addition, a wide age range was included in this study, and geriatric problems caused by age were not considered, further studies are needed in which age groups are evaluated separately or additional diseases brought by age are specifically examined. Despite all this, we believe that the present study will make significant contributions to the literature. Because in previous studies, aerobic exercise program in PwMS was given as an inpatient or home program, but there are few studies in which both groups were included and compared. In our study, we found that both groups had similar effects and we think that it is more advantageous to prefer the home program first. Considering that MS is a lifelong disease, exercise programs should be made a lifestyle. Programs given under inpatient supervision may not be accessible every day of the year due to cost, hospital availability, workload, or social reasons, and may prevent the individual from continuing his daily life. However, with a home-based aerobic exercise program planned according to the person's capacity, the individual can both continue his daily life and protect himself against the negative symptoms of the disease. 


\section{CONCLUSION}

Aerobic exercise has been observed to improve MS-related symptoms and functionality, in addition to increased cardiorespiratory capacity. Often exercise programs are given under supervision and are believed to be more successful; in this study, the home program was found to have similar benefits for patients. We think that home-based exercise program should be preferred primarily in terms of cost-effectiveness.

\section{ETHICAL DECLARATIONS}

Ethics Committee Approval: The study was carried out with the permission of University of Health Sciences, Ankara Dişkapi Yildirim Beyazit Health Research Center Ethics Committee (Date: 07.01.2019, Decision No: 58/22).

Informed Consent: Because the study was designed retrospectively, no written informed consent form was obtained from patients.

Referee Evaluation Process: Externally peer-reviewed.

Conflict of Interest Statement: The authors have no conflicts of interest to declare.

Financial Disclosure: The authors declared that this study has received no financial support.

Author Contributions: All of the authors declare that they have all participated in the design, execution, and analysis of the paper, and that they have approved the final version.

\section{REFERENCES}

1. Trapp BD, Stys PK. Virtual hypoxia and chronic necrosis of demyelinated axons in multiple sclerosis. Lancet Neurol 2009;8(3):280-91.

2. Lederman RJ. Bradley's neurology in clinical practice. JAMA. 2012;308(16):1694.

3. Brown $\mathrm{RH}$, Ropper $\mathrm{AH}$, Adams RD, et al. Adams and Victor's principles of neurology: Univerza v Ljubljani, Medicinska fakulteta; 2014.

4. Lublin FD. Clinical features and diagnosis of multiple sclerosis. Neurolog Clin 2005;23(1):1-15.

5. DeLisa JA, Gans BM, Walsh NE. Physical medicine and rehabilitation: principles and practice: Lippincott Williams \& Wilkins; 2005.

6. DeLisa JA, Gans BM. Fiziksel tıp ve rehabilitasyon: ilkeler ve uygulamalar: Güneş Tıp Kitabevleri; 2007.

7. Beyazova M, Kutsal YG. Fiziksel tıp ve rehabilitasyon: Güneş Tıp Kitabevleri; 2016.

8. Ardıç F. Egzersiz reçetesi. Türk Fiz Tıp Rehab Derg 2014;60:1-8.

9. Alphonsus KB, Su Y, D'Arcy C. The effect of exercise, yoga and physiotherapy on the quality of life of people with multiple sclerosis: Systematic review and meta-analysis. Complement Ther Med 2019;43:188-95.

10. Motl RW, McAuley E, Snook EM. Physical activity and multiple sclerosis: a meta-analysis. Mult Scler 2005;11(4):459-63.

11. Devasahayam AJ, Chaves AR, Lasisi WO, et al. Vigorous cool room treadmill training to improve walking ability in people with multiple sclerosis who use ambulatory assistive devices: a feasibility study. BMC Neurol 2020;20(1):33.

12. Ensari I, MotI RW, Pilutti LA. Exercise training improves depressive symptoms in people with multiple sclerosis: results of a meta-analysis. J Psychosom Res 2014;76(6):465-71.

13. Pilutti LA, Greenlee TA, Motl RW, et al. Effects of exercise training on fatigue in multiple sclerosis: a meta-analysis. Psychosom Med 2013;75(6):575-80.

14. Sandroff BM, Pilutti LA, Benedict RH, et al. Association between physical fitness and cognitive function in multiple sclerosis: does disability status matter? Neurorehabil Neural Repair 2015;29(3):214-23.
15. Motl RW, Sandroff BM. Benefits of exercise training in multiple sclerosis. Curr Neurol Neurosci Rep 2015;15(9):62.

16. Tantucci $C$, Massucci M, Piperno R, et al. Energy cost of exercise in multiple sclerosis patients with low degree of disability. Mult Scler J 1996;2(3):161-7.

17. Mostert $\mathrm{S}$, Kesselring J. Effects of a short-term exercise training program on aerobic fitness, fatigue, health perception and activity level of subjects with multiple sclerosis. Mult Scler 2002;8(2):161-8.

18. Ertekin Ö, Özakbas S, Idiman E, et al. Quality of life, fatigue and balance improvements after home-based exercise program in multiple sclerosis patients. Noro-Psikyatri Arsivi. 2012;49(1):33.

19. Laboratories ACoPSfCPF. ATS statement: guidelines for the six-minute walk test. Am J Respir Crit Care Med 2002;166:111-7.

20. Moore G, Durstine JL, Painter $P$, et al. Acsm's exercise management for persons with chronic diseases and disabilities, 4E: Human Kinetics; 2016.

21. Rw B, Smith M. Interrater reliability of a modified Ashworth scale of muscle spasticity. Phys Ther 1987;67(2):206-7.

22. Kurtzke JF. Rating neurologic impairment in multiple sclerosis: an expanded disability status scale (EDSS). Neurology 1983;33(11):1444-.

23. Krupp LB, Alvarez LA, LaRocca NG, et al. Fatigue in multiple sclerosis. Arch Neurol 1988;45(4):435-7.

24. Balaban Ö, Nacır B, Erdem H, et al. The Evaluation Of The Balance Function. J Phys Med Rehabil Sci. 2009;12(3):133-9.

25. Vickrey B, Hays RD, Harooni R, et al. A health-related quality of life measure for multiple sclerosis. Qual Life Res 1995;4(3):187-206.

26. Kileff J, Ashburn A. A pilot study of the effect of aerobic exercise on people with moderate disability multiple sclerosis. Clin Rehabil 2005;19(2):165-9.

27. Simeoni M, Auquier P, Fernandez $\mathrm{O}$, et al. Validation of the multiple sclerosis international quality of life questionnaire. Multiple Sclerosis Journal. 2008;14(2):219-30.

28. Thoumie P, Mevellec E. Relation between walking speed and muscle strength is affected by somatosensory loss in multiple sclerosis. J Neurol Neurosurg Psychiatry. 2002;73(3):313-5.

29. Savci S, Inal-Ince D, Arikan $\mathrm{H}$, et al. Six-minute walk distance as a measure of functional exercise capacity in multiple sclerosis. Disabil Rehabil 2005;27(22):1365-71.

30. Devasahayam AJ, Downer MB, Ploughman M. The effects of aerobic exercise on the recovery of walking ability and neuroplasticity in people with multiple sclerosis: a systematic review of animal and clinical studies. Multiple sclerosis international. 2017;2017.

31. Latimer-Cheung AE, Pilutti LA, Hicks AL, et al. Effects of exercise training on fitness, mobility, fatigue, and health-related quality of life among adults with multiple sclerosis: a systematic review to inform guideline development. Arch Phys Med Rehabil 2013;94(9):1800-28. e3.

32. Langeskov-Christensen M, Heine M, Kwakkel G, et al. Aerobic capacity in persons with multiple sclerosis: a systematic review and meta-analysis. Sports Med 2015;45(6):905-23.

33. Motl RW, Fernhall B. Accurate prediction of cardiorespiratory fitness using cycle ergometry in minimally disabled persons with relapsing-remitting multiple sclerosis. Arch Phys Med Rehabil 2012;93(3):490-5.

34. Motl RW, Smith DC, Elliott J, et al. Combined training improves walking mobility in persons with significant disability from multiple sclerosis: a pilot study. J Neurol Phys Ther 2012;36(1):32-7.

35. Klaren RE, Sandroff BM, Fernhall $B$, et al. Comprehensive profile of cardiopulmonary exercise testing in ambulatory persons with multiple sclerosis. Sports Med 2016;46(9):1365-79.

36. Beckerman H, de Groot V, Scholten MA, et al. Physical activity behavior of people with multiple sclerosis: understanding how they can become more physically active. Phys Ther 2010;90(7):1001-13.

37. Kempen JC, de Groot V, Knol DL, et al. Self-reported fatigue and energy cost during walking are not related in patients with multiple sclerosis. Arch Phys Med Rehabil 2012;93(5):889-95.

38. Coote S, O'Dwyer C. Energy expenditure during everyday activities-a study comparing people with varying mobility limitations due to multiple sclerosis and healthy controls. Disabil Rehabil 2014;36(24):2059-64. 